\title{
PLANT PRODUCTION POSSIBILITIES ON A HEAVY METAL CONTAMINATED SOIL WITH THE PURPOSE OF BIOREFINERY
}

ÁGNES DERGEZ ${ }^{1}$, L. BLASKÓ ${ }^{2}$, DIÁNA BORDÁS ${ }^{1}$, GY. ZSIGRAI $^{2}$, I. KISS $^{1}$, S. SZABÓ $^{2}$, 1 Institute for Biotechnology of Bay Zoltán Foundation for Applied Research 2 University of Debrecen, CAAES RISF Karcag Research Institute

\author{
Keywords \\ biorefinery, heavy metal pollution, phytoremediation,
}

\section{Summary}

Significant part of not cultivated area of Hungary is not suitable for agricultural utilization because of industrial pollution. Technologies of biorefinery make reutilization of contaminated areas possible. Biomass of plants produced on polluted soils can be raw material of valuable products. Applicability of biorefinery was tested on a heavy metal polluted soil, where the contamination originated from previous mining activity. Complete biomass utilization was aimed to obtain cosmetic ingredients, pharmaceutical agents, and precursors. During our research work 88 plant species and varieties were produced and tested for potential utilizable components. Levels of possible contaminants in these plants were monitored, and amounts of carbohydrates, protein, organic acid and cellulose were determined as well. Different plant extracts were tested as potential sources of biologically effective components or as raw materials for lactic acid fermentation. Our results show that biorefinery is a real possibility for utilization of polluted areas. Numerous plants could be cultivated on contaminated areas without increased levels of contaminants in their tissues, thus they can be sources of valuable compounds.

\section{INTRODUCTION}

Biorefinery is a complex technology where biomass can be converted to useful materials (e.g. fuels, solvents, plastics, cosmetic and pharmaceutical materials) or energy carriers in an integrated manner, thereby it can maximize the economic value of the biomass used while reducing the waste streams produced $[8,3]$. Utilization of arable lands to produce non-food plants causes social resistance currently; however, there are some so called brown field areas (suffering from industrial contamination), where agricultural use is not possible due to high levels of contaminants, such as heavy metal ions. Some plants are able to grow in heavy metal polluted environment $[6,5]$ and do not accumulate heavy metal ions in toxic levels for humans. Sorghum and sunflower can easily absorb and translocate heavy metals to plant foliage [7]. However, accumulation of heavy metal ions in plants is limited by their phytotoxicity at levels safe for humans and animals. Various plants, such as lavender contain lots of effective compounds, which can be utilized for different industrial purposes, like isolation of antimicrobial agents [2]. Moreover, plants of high sugar or starch content, such as sorghum or millet, provide valuable raw materials for ethanol or lactic acid production [10]. Lactic acid might be utilizable to produce biodegradable plastic [1].

In 2007 a consortium was generated by the Elgoscar-2000 Ltd., by the Institute for Biotechnology and the Institute of Logistics and Production Engineering of Bay Zoltán Foundation for Applied Research, by the Karcag Research Institute of CAAES RISF of Debrecen University and by the Biocentrum Ltd for the purpose of execution of a scientific research program supported by the Hungarian National Office for Research and Technology on the field of integration of phytoremediation of different polluted fields and of plant biomass biorefinery. The main goal of the project was to elaborate a new complex 
technology, which can guarantee the proper treatment and the profitable utilization of polluted fields. For this purpose biomass production ability and potential availability for industrial utilization of numerous plant species and varieties were tested in a field experiment and in a pot trial on a soil extremely polluted by heavy metals.

Some results of the pot experiment are demonstrated in this paper to illustrate our research work and our screening technologies.

\section{MATERIAL AND METHODS}

With the purpose of fulfillment of our scientific program regarding to utilization of heavy metal polluted fields a pot experiment (Fig. 1) was carried out at Gyöngyösoroszi in 2008.

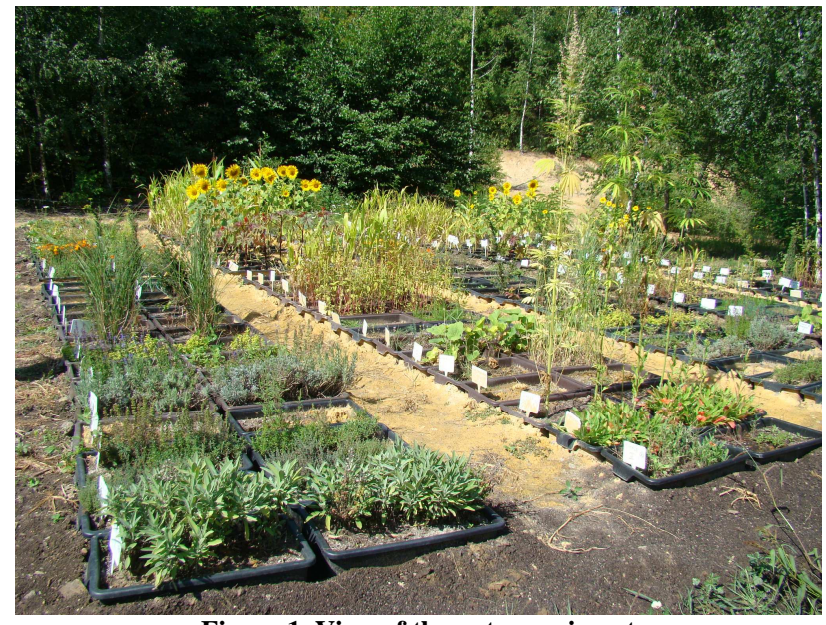

Figure 1. View of the pot experiment

Great amounts of heavy metal containing slop were arisen at the Mátra Metal Mines during ore enrichment processes. Some of this slop was filled into two types of pots. One type was of $50 \mathrm{dm}^{3}$ for herbaceous plants and the other type was of $300 \mathrm{dm}^{3}$ for arboreal plants. Biomass production capacity, heavy metal tolerance and potential availability for industrial utilization of 88 different plant species and varieties were tested in this experiment. The total number of the plots was 428 .

Some chemical properties of the used slop are shown in the Table 1. These analytical data proved the significant $\mathrm{Zn}$-, $\mathrm{Cu}-, \mathrm{Cd}-$, and $\mathrm{Pb}$-pollution of the slop. Ground limestone of 5 $\mathrm{m} \%$ was mixed with the slop to mitigate the solubility of the heavy metal compounds. The used slop did not contain any phosphorus, hence artificial P-fertilization (analogous with $200 \mathrm{~kg} \mathrm{P}_{2} \mathrm{O}_{5} \mathrm{ha}^{-1}$ dose) was applied in each plot.

The two-factorial pot experiment provided possibilities to examine the tolerance of the tested plants (88 species) to heavy metal contaminations and the effects of different TERRASOL compost doses (analogous with 30 tha $^{-1}$ and 50 tha $^{-1}$ doses) on the biomass production of these plant species. 
At the beginning of blooming or ripening plant samples were taken from the plant standings of plots to establish the biomass production and to make different chemical analysis.

Some chemical properties of the used slop polluted by heavy metals

Table 1

\begin{tabular}{|c|c|c|c|c|c|c|c|c|}
\hline \multirow{3}{*}{$\mathbf{p H}\left(\mathrm{H}_{2} \mathrm{O}\right)$} & \multirow{3}{*}{ pH(KCl) } & \multirow{3}{*}{ y1 } & \multirow{3}{*}{$\begin{array}{c}\text { Humic } \\
\text { matter } \\
\text { content } \\
(\%)\end{array}$} & \multicolumn{5}{|c|}{ AL-soluble } \\
\hline & & & & $\mathbf{P}_{2} \mathbf{O}_{5}$ & $\mathrm{~K}_{2} \mathrm{O}$ & $\mathbf{C a}$ & $\mathrm{Mg}$ & $\mathbf{N a}$ \\
\hline & & & & \multicolumn{5}{|c|}{$\left(\mathrm{mg} \mathrm{kg}^{-1}\right)$} \\
\hline 6,63 & 6,37 & 10 & 1,24 & $<2$ & 112 & 21470 & 1178 & 43 \\
\hline \multicolumn{9}{|c|}{ KCl+EDTA soluble } \\
\hline $\mathbf{Z n}$ & $\mathbf{C u}$ & $\mathbf{F e}$ & Mn & $\mathrm{Cr}$ & Co & $\mathbf{N i}$ & $\mathbf{C d}$ & $\mathbf{P b}$ \\
\hline \multicolumn{9}{|c|}{$\left(\mathrm{mg} \mathrm{kg}^{-1}\right)$} \\
\hline 648 & 230 & 258 & 270 & 4 & 2,4 & 2 & 6,3 & 356 \\
\hline \multicolumn{9}{|c|}{ Total element content } \\
\hline $\mathbf{Z n}$ & $\mathbf{C u}$ & $\mathbf{F e}$ & Mn & $\mathrm{Cr}$ & Co & $\mathbf{N i}$ & $\mathbf{C d}$ & $\mathbf{P b}$ \\
\hline \multicolumn{9}{|c|}{$\left(\mathrm{mg} \mathrm{kg}^{-1}\right)$} \\
\hline 1715 & 675 & 42666 & 964 & 33 & 10 & 7 & 7 & 473 \\
\hline
\end{tabular}

Establishment of common plant ingredients

$0.2 \mathrm{~g}$ plant sample was homogenized in $0.1 \mathrm{~N}$ filtered $\mathrm{H}_{2} \mathrm{SO}_{4}$ of $5 \mathrm{ml}$ and centrifuged for 20 min $(13500 \mathrm{rpm})$. The supernatant was diluted by $\mathrm{H}_{2} \mathrm{SO}_{4}$ to 20 -fold and analyzed by GynkoTek isocratic HPLC arrangement, on CAR-H column and at $30^{\circ} \mathrm{C}$, and the mobile phase was $0.01 \mathrm{~N}$ filtered $\mathrm{H}_{2} \mathrm{SO}_{4}$. Sugars were detected by refractive index detector and the organic acids were detected by UV detector. Data were integrated by the Chromeleon program. Cellulose content was determined from $1 \mathrm{~g}$ plant sample by the nitric acid-ethanol mixture methodology [9]. During the protein assay $0.2 \mathrm{~g}$ plant sample was homogenized in $0.1 \mathrm{~N} \mathrm{NaOH}$ of $6 \mathrm{ml}$ and incubated in water-bath at $60{ }^{\circ} \mathrm{C}$ for 2 hours and centrifuged for 10 minutes at $13000 \mathrm{rpm}$. The supernatant was diluted by distilled water to 20 -fold. $250 \mu 1$ taken from the prepared sample was analyzed by the Lowry method [4]. The concentration of the reduced Folin's reagent is measured by absorbance with a Unicam He $\lambda$ ios $\alpha$ UV-VIS spectrophotometer at $750 \mathrm{~nm}$.

Heavy metal analysis

Amounts of heavy metal contaminants of the plant and soil samples were determined by Bálint Analitika Ltd. (Hungary) using HP 4500 plus ICP-MS.

\section{Lactic acid fermentation}

Shoots of the plants were physically crushed and fractioned by an Angel juice extractor. The liquid phases were tested as potential medium for lactic acid fermentation. Lactobacillus delbruckii spp. lactis was applied to convert the sugar content of plant extracts to lactic acid. The liquid phase was sterilized at $115{ }^{\circ} \mathrm{C}$ for 30 minutes then centrifuged at $5000 \mathrm{rpm}$ for 20 minutes. The inoculum was grown in modified DSM-186 medium and incubated at $37{ }^{\circ} \mathrm{C}$ for 72 hours. Inoculum of $20 \mu \mathrm{l}$ was added to $1 \mathrm{ml}$ supernatant of the liquid phase and incubated at $37{ }^{\circ} \mathrm{C}$ for 48 hours. The initial glucose content and the amount of produced lactic acid were measured by HPLC. 


\section{Biogas production}

After crushing and fractioning the solid phase of grain sorghum were tested for biogas production. The reactor volume was $1000 \mathrm{ml} .800 \mathrm{ml}$ anaerob sludge and $20 \mathrm{~g}$ dried solid phases were applied. Reactors were incubated at $37^{\circ} \mathrm{C}$. The produced biogas were trapped and monitored for the total amount of gases in $\mathrm{ml}$ for 30 days. The methane content of the biogas was investigated at the end of the exponential phase $\left(13^{\text {th }}\right.$ day). The gas analysis was carried out by Gas Chromatograph with $5975 \mathrm{MS}$ Detector (Front Inlet: $250{ }^{\circ} \mathrm{C}$; split rate: 1:50; GS-GASPRO $(60 \mathrm{~m} \times 0,320 \mathrm{~mm})$ column; at $40^{\circ} \mathrm{C}$ for $6 \mathrm{~min}$., heating to $130{ }^{\circ} \mathrm{C}$ by 30 ${ }^{\circ} \mathrm{C} / \mathrm{min}$; at $130^{\circ} \mathrm{C}$ for 2,0 min.; methode: C1-C2GAS.M.; detecting in AUTO tune mode; carrier gas: He (Linde).

\section{RESULTS AND DISCUSSION}

\section{Heavy metal pollution tolerance of the tested plant species}

On the basis of the experimental data we established that the amount of biomass was increased by the compost application in case of a part of the tested plant species and varieties. Data of the Table 2 show the positive effect of the applied TERRASOL compost on the green biomass of some plant species. We must mention that the extremely high compost dose of $50 \mathrm{t} \mathrm{ha}^{-1}$ decreased the amount of the green biomass in case of several plant species. Under the circumstances of the experiment buckwheat, grain sorghum, energy poplars, energy willows, hemp, purple coneflower, white mustard and sunflower could reach relatively high amount of biomass.

Effect of compost doses on the green biomass $\left(\mathrm{g} \mathrm{m}^{-1}\right)$ of some plant species grown in a heavy metal polluted soil (Gyöngyösoroszi, 2008)

\begin{tabular}{|c|c|c|c|}
\hline \multirow{2}{*}{ Plant species/varieties } & \multicolumn{3}{|c|}{ Compost treatments } \\
\hline & control & 30 tha $^{-1}$ & 50 tha $^{-1}$ \\
\hline grain sorghum (Alföldi 1) & 0 & 640 & 320 \\
\hline sweet sorghum (Cellu) & 0 & 694 & 1032 \\
\hline grain sorghum (Albita) & 0 & 434 & 408 \\
\hline grain sorghum (GK Emese) & 0 & 416 & 378 \\
\hline sweet sorghum (Monori édes) & 0 & 502 & 706 \\
\hline sweet sorghum (Róna 1) & 0 & 592 & 584 \\
\hline sudan grass (Gardavan) & 0 & 370 & 482 \\
\hline grain sorghum (Zádor) & 0 & 360 & 306 \\
\hline sweet sorghum (Sucrosorgo) & 0 & 196 & 566 \\
\hline hemp & 0 & 1016 & 848 \\
\hline evening star & 0 & 286 & 312 \\
\hline lozenge & 22 & 106 & 156 \\
\hline French marigold & 0 & 650 & 664 \\
\hline Arundo donax & 220 & 633 & 426 \\
\hline
\end{tabular}


We established that the following plant species and varieties could tolerate the unfavorable chemical, hydrological and microclimatic conditions of the heavy metal polluted trial site: each sweet sorghum hybrid, castor-oil plant, chicling vetch, amaranth, lozenge, coriander, millet, facelia, bluebottle, oenothera, evening star, red poppy, Arundo donax, onion, French marigold, bean, dill, white clover. From the tested plant species and varieties the following ones could not tolerate the unfavorable ecological conditions of the trial site: maize, sunflower, pumpkin, lupin, perennial flax, Canary grass, pine, spruce, oak, wattle, rosemary, milfoil, anise, basil, green pea, poppy, celery and parsley. The sensitivity of these plant species to heavy metal contamination was manifested in limited germination. Anthocyanine pigmentations were observable on the young seedlings and their growth was slow. As a consequence of these processes mentioned above, the sensitive indicator plants died in June and July when additional climatic stress (high air temperature) was formed out.

We observed that the actual biomass production of the tolerant plant species covered on a part of their genetic potential only. By our opinion, the biomass production of these plant species can be increased by improvement of agroecological conditions (water regime, organic matter content, nutrient supply, etc.) of production sites polluted by heavy metals.

Analysis of heavy metal contents of the produced biomass

After preparation of plant samples by juicer, 98-100\% of heavy metal ions could be detected in liquid fraction. We found that heavy metals were concentrated in roots (Table 3) consequently. The tested plants did not transport them to their shoots. The compost treatments had no obvious influences on the heavy metal uptake and distribution.

Heavy metal recovery was calculated for different sorghum varieties based on their biomass yields and the measured heavy metal contents. Similarly to the heavy metal distribution, the applied compost treatments did not resulted in observable differences in the heavy metal uptake (Fig. 2). However, approximately $0.5-1 \mathrm{~kg} \mathrm{ha}^{-1}$ zinc was recovered in the biomass of Cellu and Monori édes sweet sorghum varieties. This founding indicates the possibility of utilization of these varieties for phytoremediational purposes.

Table 3

Heavy metal contents of different parts of some plant species and varieties

\begin{tabular}{|c|c|c|c|c|c|c|c|c|c|}
\hline \multirow{3}{*}{ Crop varieties } & \multirow{3}{*}{$\begin{array}{l}\text { crop } \\
\text { part }\end{array}$} & \multicolumn{2}{|c|}{ Cd } & \multicolumn{2}{|c|}{$\mathbf{C u}$} & \multicolumn{2}{|c|}{$\mathbf{P b}$} & \multicolumn{2}{|c|}{$\mathbf{Z n}$} \\
\hline & & \multicolumn{8}{|c|}{ compost treatments $\left(\mathrm{t} \mathrm{ha}^{-1}\right)$} \\
\hline & & 30 & 50 & 30 & 50 & 30 & 50 & 30 & 50 \\
\hline \multirow{2}{*}{ Albita (sorghum) } & shoot & 0.57 & 0.19 & 1.59 & 0.54 & 0.65 & 1.49 & 18.10 & 10.40 \\
\hline & root & 7.71 & 1.69 & 43.20 & 11.40 & 204.00 & 193.00 & 486.00 & 31.90 \\
\hline \multirow{2}{*}{ Cellu (sorghum) } & shoot & 1.46 & 2.16 & 1.37 & 3.42 & 1.40 & 6.28 & 30.40 & 32.60 \\
\hline & root & 5.62 & 2.38 & 26.10 & 14.50 & 147.00 & 205.00 & 94.40 & 39.10 \\
\hline \multirow{2}{*}{$\begin{array}{l}\text { GK Emese } \\
\text { (sorghum) }\end{array}$} & shoot & 0.31 & 0.31 & 0.53 & 2.06 & 0.70 & 12.80 & 27.00 & 21.10 \\
\hline & root & 4.78 & 2.59 & 17.20 & 13.60 & 92.20 & 211.00 & 85.00 & 112.00 \\
\hline \multirow{2}{*}{$\begin{array}{c}\text { Monori édes } \\
\text { (sorghum) }\end{array}$} & shoot & 1.86 & 0.17 & 2.67 & 2.51 & 2.87 & 1.04 & 99.80 & 30.60 \\
\hline & root & 6.56 & 2.59 & 12.00 & 49.10 & 384.00 & 226.00 & 96.80 & 110.00 \\
\hline \multirow{2}{*}{ Róna 1 (sorghum) } & shoot & 0.44 & 0.18 & 0.57 & 1.05 & 0.97 & 1.33 & 23.50 & 11.40 \\
\hline & root & 3.23 & 2.02 & 9.03 & 20.00 & 8.77 & 124.00 & 186.00 & 35.90 \\
\hline \multirow[t]{2}{*}{ Zádor (sorghum) } & shoot & 0.69 & 0.11 & 1.23 & 0.55 & 1.90 & 1.00 & 30.50 & 12.30 \\
\hline & root & 7.22 & 1.29 & 31.60 & 8.19 & 315.00 & 32.30 & 216.00 & 87.00 \\
\hline balm & shoot & 0.97 & 0.13 & 74.70 & 17.20 & 95.20 & 14.30 & 136.00 & 36.10 \\
\hline lavender & shoot & 0.23 & 0.16 & 37.30 & 12.40 & 27.90 & 27.70 & 78.30 & 35.50 \\
\hline
\end{tabular}




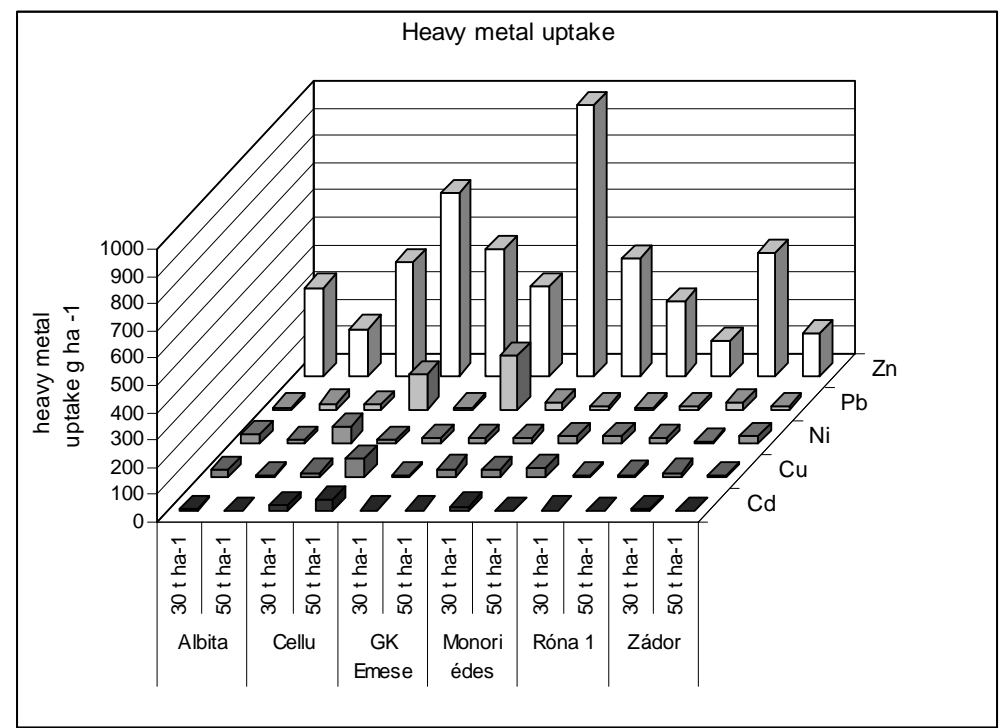

Figure 2. Effects of compost doses $\left(30\right.$ and $\left.50 \mathrm{t} \mathrm{ha}^{-1}\right)$ on the heavy metal uptake of different sorghum varieties

\section{Analysis of common plant ingredients}

Amounts of common plant ingredients, for example cellulose, sugars, organic acids and proteins were measured in the biomass of all tested plant species grown on a soil extremely polluted by heavy metals and treated with different compost doses. According to the experimental data, the applied compost doses had no effect on amounts of the monitored plant ingredients. While the biomass production was much lower in the experiment than the usual biomass production, the proportion of these compounds were not affected by the presence of heavy metal ions.

\section{Lactic acid fermentation}

The shoots of different Sorghum varieties were ground in an Angel juice extractor, and the liquid phases of the produced samples were inoculated with Lactobacillus delbruckii spp. lactis cells. In some cases, the proportion of lactic acid to glucose was higher than one; consequently, other carbon sources from the plant extract could be used for lactic acid fermentation by the bacterium. Compost treatment did not affect the effectiveness of lactic acid production. In some cases the yield of lactic acid was more than $50 \mathrm{~g} \mathrm{l}^{-1}$ (Table 4), which can be considered to be quite high concentration in comparison with the literature data [10]. The high lactic acid concentration is beneficial for the purification of lactic acid, which might be utilizable to produce polylactate [1].

\section{Biogas production}

The solid phase of grain sorghum biomass was tested for energetic application. We established that the total amount of biogas formed was higher in case of compost treatment, but the methane content of the biogas measured at the end of the exponential phase of gas 
formation was higher in case of biomass samples originated from untreated pots (Fig. 3A and 3B).

Table 4

Lactic acid fermentation from the liquid phase of different sorghum varieties originated from pots treated with different compost doses $\left(30\right.$ and $\left.50 \mathrm{t} \mathrm{ha}^{-1}\right)$

\begin{tabular}{llrr}
\hline \multicolumn{3}{c}{ Lactic acid fermentation } \\
\hline Albita & Plants & glucose $\mathrm{g} \mathrm{I}^{-1}$ & $\begin{array}{r}\text { produced lactic acid } \\
\mathrm{g} \mathrm{I}^{-1}\end{array}$ \\
Cellu & $30 \mathrm{t} \mathrm{ha}^{-1}$ & 40.61 & 24.29 \\
& $50 \mathrm{t} \mathrm{ha}^{-1}$ & 25.29 & 8.52 \\
GK Emese & $30 \mathrm{t} \mathrm{ha}^{-1}$ & 60.14 & 22.37 \\
& $50 \mathrm{t} \mathrm{ha}^{-1}$ & 20.32 & 20.30 \\
Monori édes & $30 \mathrm{t} \mathrm{ha}^{-1}$ & 98.54 & 54.28 \\
& $50 \mathrm{t} \mathrm{ha}^{-1}$ & 66.79 & 52.25 \\
Róna 1 & $30 \mathrm{t} \mathrm{ha}^{-1}$ & 53.43 & 31.75 \\
& $50 \mathrm{t} \mathrm{ha}^{-1}$ & 93.85 & 53.65 \\
Zádor & $30 \mathrm{t} \mathrm{ha}^{-1}$ & 48.81 & 47.09 \\
& $50 \mathrm{t} \mathrm{ha}^{-1}$ & 182.37 & 62.53 \\
& $30 \mathrm{t} \mathrm{ha}^{-1}$ & 86.82 & 60.71 \\
& $50 \mathrm{t} \mathrm{ha}^{-1}$ & 107.23 & 63.85 \\
\hline
\end{tabular}

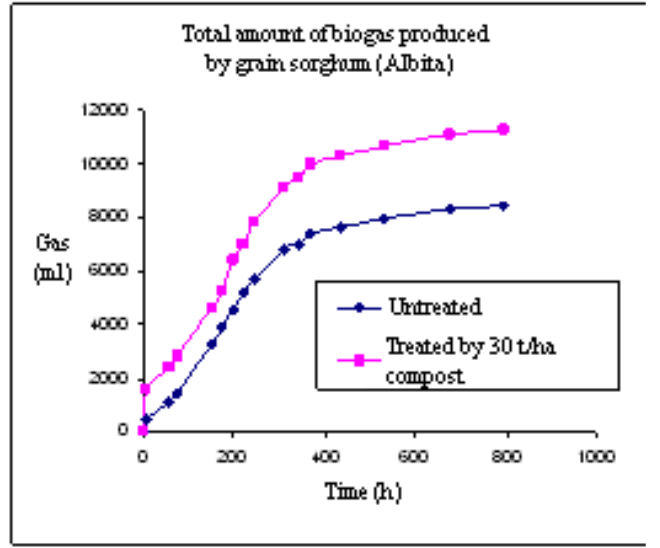

A

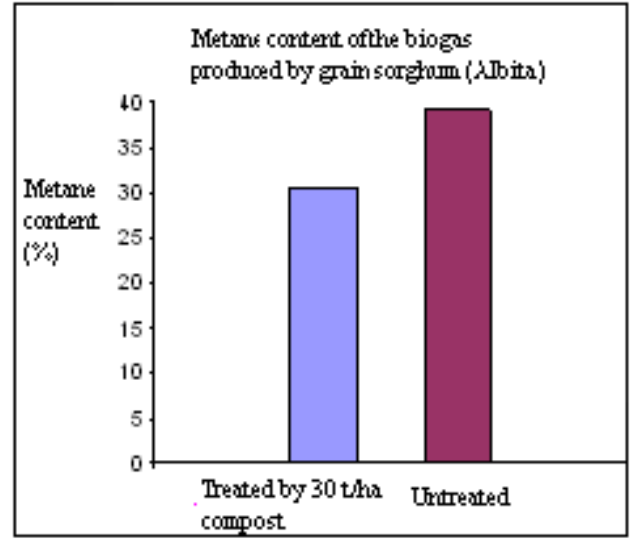

Figure 3. Biogas production of grain sorghum

A: Total amount of biogas B: Methane content of the biogas at the end of the exponential phase (untreated and treated by $30 \mathrm{t} \mathrm{ha}^{-1}$ compost)

We found that the methane content changed during the incubation, hence definite effect of the compost treatment on the quality of formed biogas could not be observable. 


\section{CONCLUSIONS}

On the basis of the experimental data we established that some plant species can adapt to the unfavorable ecological conditions of heavy metal polluted soils. The amount of biomass of these plant species was increased by the compost application significantly.

According to the results, biomass of numerous plant species can be utilized as raw material of valuable products, like lactic acid, biogas and biologically active compounds (e.g. antimicrobials), without significant accumulation of heavy metal contaminants. These results suggest that plants cultivated on heavy metal contaminated areas can be valuable sources of base materials for biorefinery.

Development of a complex purification method of these active compounds is necessary, taking the presence of heavy metal contamination into consideration.

\section{ACKNOWLEDGEMENTS}

This work was supported by the grants NKFP_07_4-BIOFINOM.

\section{REFERENCES}

1. Achmad, F. - Yamane, K. - Quan, S. - Kokugan, T.: (2009) Synthesis of polylactic acid by direct polycondensation under vacuum without catalysts, solvents and initiators. Chemical Engineering Journal. 151. 342-350

2. Adam, K. - Sivropoulou, A. - Kokkini, S. - Lanaras, T. - Arsenakis, M.: (1998) Antifungal Activities of Origanum vulgare subsp. hirtum, Mentha spicata, Lavandula angustifolia, and Salvia fruticosa Essential Oils against Human Pathogenic Fungi. J. Agric. Food Chem. 46. 1739-1745.

3. Kaparaju, P. - Serrano, M. - Thomsen, A. B. - Kongjan, P. - Angelidaki, I.: (2009) Bioethanol, biohydrogen and biogas production from wheat straw in a biorefinery concept. Bioresource Technology. 100. 2562-2568.

4. Lowry, O. H. - Rosebrough, N. J. - Farr, A. L. - Randall, R. J.: (1951) Protein measurement with the Folin phenol reagent. J. Biol. Chem. 193. 265-275.

5. Máthéné Gáspár G. - Anton A.: (2004.) Toxikuselem-szennyeződés káros hatásainak mérséklése fitoremediációval. Agrokémia és Talajtan. 53. 413-432.

6. Murányi, A. - Ködöböcz, L.: (2008) Heavy metal uptake by plants in different phytoremediation treatments. Cereal Res. Commun. 36. 387-390.

7. Murillo, J. M. - Maranon, T. - Cabrera, F. - Lopez, R.: (1999) Accumulation of heavy metals in sunflower and sorghum plants affected by the Guadiamar spill. The Science of the Total Environment. 242. 281292.

8. Ohara, H.: (2003) Biorefinery. Appl. Microbiol. Biotechnol. 62. 474-477.

9. Wang, Z. H.: (1995) Assay and Examination of Pulp Manufacture and Papermaking. Light Industry Press, Bei Jing, China.

10. Zhan, X. - Wang, D. - Tuinstra, M. R. - Bean, S. - Seib, P. A. -- Sun, X. S.: (2003) Ethanol and lactic acid production as affected by sorghum genotype and location. Industrial Crops and Products. 18. 245255. 